\title{
Prognostic relevance of mutations and copy number alterations assessed with targeted next generation sequencing in IDH mutant grade Il glioma
}

\author{
Maarten M. J. Wijnenga ${ }^{1} \cdot$ Pim J. French ${ }^{1} \cdot$ Hendrikus J. Dubbink ${ }^{2} \cdot$ Winand N. M. Dinjens $^{2} \cdot$ Peggy N. Atmodimedjo $^{2}$. \\ Johan M. Kros ${ }^{2} \cdot$ Ruth Fleischeuer $^{3} \cdot$ Clemens M. F. Dirven $^{4} \cdot$ Arnaud J. P. E. Vincent $^{4} \cdot$ Martin J. van den Bent $^{1}$
}

Received: 7 February 2018 / Accepted: 8 April 2018 / Published online: 16 April 2018

(C) The Author(s) 2018

\begin{abstract}
Background At current prognostication of low grade glioma remains suboptimal and might be improved with additional markers. These may guide treatment decisions, in particular on early adjuvant therapy versus wait and see after surgery. Methods We used a targeted Next-Generation Sequencing panel to assess mutational and copy number status of selected genes and chromosomes in a consecutive series of adult grade II supratentorial glioma, and assessed the impact of molecular markers of interest on overall survival.

Results 207 IDH mutated grade II glioma samples were analyzed with a median follow-up of 6.9 years. Loss of region 9p21.3 did not show a correlation with outcome in $I D H$ mutated $1 \mathrm{p} / 19 \mathrm{q}$-codeleted oligodendroglioma or $I D H$ mutated astrocytoma. We found a significant shorter overall survival with univariable analysis in $I D H$ mutated astrocytoma patients with trisomy of chromosome 7 (Log rank $\mathrm{P}=0.044)$ and in $I D H$ mutated $1 \mathrm{p} / 19 \mathrm{q}$-codeleted oligodendroglioma patients with a PTEN mutation (Log rank $\mathrm{P}=0.033$ ). We could not validate these findings in multivariate analysis or in the TCGA dataset. Conclusions Loss of $9 \mathrm{p} 21.3$ is not associated with outcome in a molecularly defined cohort of grade II glioma and therefore it remains unclear if loss of 9p21.3 can be used as additional marker of anaplasia or to guide treatment decisions. Trisomy of chromosome 7 in IDH mutated astrocytoma and PTEN mutations in IDH mutated oligodendroglioma are potential markers of poor prognosis, but require confirmation in larger series.
\end{abstract}

Keywords Glioma $\cdot$ Low-grade $\cdot$ Molecular markers $\cdot$ IDH $\cdot 9$ p21.3 $\cdot 7 \mathrm{q}$

\section{Introduction}

Electronic supplementary material The online version of this article (https://doi.org/10.1007/s11060-018-2867-8) contains supplementary material, which is available to authorized users.

Martin J. van den Bent

m.vandenbent@erasmusmc.nl

1 Department of Neurology, Brain Tumor Center at Erasmus MC Cancer Institute, PO Box 5201, 3008AE Rotterdam, The Netherlands

2 Department of Pathology, Brain Tumor Center at Erasmus MC Cancer Institute, Rotterdam, The Netherlands

3 Department of Pathology, St Elisabeth Hospital, Tilburg, The Netherlands

4 Department of Neurosurgery, Brain Tumor Center at Erasmus MC Cancer Institute, Rotterdam, The Netherlands
In 2016 the World Health Organization Classification of Tumors of the Central Nervous System (WHO) was updated, resulting in a major change in the classification of diffuse gliomas [1]. The 2016 WHO classification provides an integrated diagnosis of glioma by combining histopathological with genotypic features. Moreover, in the case of discrepancy between genotypic and histopathological features, the genotypic features are leading in classifying a glioma subtype. As a result the 2016 CNS WHO markedly improved the objectivity of classification and prognosis estimation as compared to the previous version [1-3].

Three clinically relevant subgroups of diffuse low-grade (grade II) gliomas are identified and recognized by the WHO 2016 classification based on two molecular markers: (1) oligodendroglioma, IDH mutant and 1p/19q-codeleted (IDHI/2 mutation in combination with presence of a co-deletion of 
the entire $1 \mathrm{p}$ and $19 \mathrm{q}$ chromosomal arms), (2) diffuse astrocytoma, IDH mutant; (IDHI/2 mutation without $1 \mathrm{p} 19 \mathrm{q}$ codeletion), and (3) diffuse astrocytoma, IDH1/2 wildtype. Other frequently reported genetic changes in glioma are CIC, FUBP1, TP53, ATRX, TERT promoter mutations and copy number changes of chromosome 7,9 , and $10[1,2$, $4,5]$. Although the 2016 CNS WHO update is robust and provides a more accurate prognosis estimation, there is still variation in outcome within the different entities and the grading of glioma is still depending on histological features. Prognostication might be further improved if additional molecular markers can be identified that correlate with prognosis. These markers may facilitate treatment decisions, in particular for early radiotherapy and adjuvant chemotherapy versus a wait and watch policy after surgery. This is in particular relevant, as the currently used criteria (age of 40, less than gross total resection) are quite arbitrary, and in some patients that are 40 years or older with a less than gross total resection, a wait and watch period of years is possible [6-8]. Thus, molecular factors showing a clinically significant relation with outcome would be highly welcome.

Several studies have tried to further stratify molecularly defined glioma, most of them in anaplastic glioma. For example, some studies showed that loss of chromosome 9p or specifically the $9 \mathrm{p} 21.3$ region is associated with a worse prognosis in various subtypes of grade III and IV glioma [9-11]. This could however not be validated in a recently published large cohort of grade II and III glioma [12]. In the present study we aimed to identify molecular prognostic markers for grade II $I D H$ mutated astrocytoma (in particular loss of 10q, trisomy of chromosome 7, PTEN mutations) and in grade II $I D H$ mutated 1p19q-codeleted oligodendroglioma (in particular loss of 9p21.3, CIC, FUBP1, and PTEN mutations). To our knowledge there are no published studies that investigated prognostic impact of these markers specifically in molecularly defined grade II glioma. Therefore, in a well-defined cohort of histologically proven supratentorial adult grade II glioma we used a targeted Next-Generation Sequencing panel for molecular classification and evaluated the prognostic value of glioma specific molecular markers.

\section{Methods}

\section{Patient selection}

For this study we used a cohort of patients from a project on extent of resection in grade II glioma [13]. Adult patients (age $\geq 18$ years) with histopathologically confirmed supratentorial grade II glioma were included. Tissue samples were collected in two Dutch hospitals (Erasmus MC Cancer Institute, Rotterdam; and Elisabeth-TweeSteden Hospital, Tilburg). Histopathological diagnosis and low grade was confirmed by a dedicated neuropathologist (J.M.K.). Timewindow of patient inclusion was 2003-2016. For clinical factors, age, KPS, type of surgery, and treatment after surgery were collected. This study was approved by the medical ethics committee of Erasmus MC.

\section{DNA extraction}

DNA was isolated from formalin-fixed-paraffin-embedded (FFPE) tissue blocks. Tissue areas with high percentage of neoplastic cells (preferably $>70 \%$, but at least $50 \%$ ) were manually macrodissected from $10 \mu \mathrm{m}$ sections. Macrodissected tissue was digested using Proteinase $\mathrm{K}$ incubation at $56{ }^{\circ} \mathrm{C}$ overnight in presence of $5 \%$ Chelex 100 resin (Bio$\mathrm{Rad})$. After overnight incubation, proteinase $\mathrm{K}$ was inactivated at $90{ }^{\circ} \mathrm{C}$ for $10 \mathrm{~min}$. Next, dissolved DNA was separated from Chelex resin and cell debris by centrifugation at $20 \mathrm{~g}$ for $5 \mathrm{~min}$. DNA concentration was measured using the Qubit 3.0 Fluorometer according to manufacturer's protocol (Life Technologies).

\section{Next-Generation-Sequencing}

We used Next-Generation Sequencing to assess mutational and copy number status of selected genes and chromosomes. The primer panel consisted of primers for glioma specific genes of interest (hot spot regions, or whole gene) and primers for highly polymorphic single nucleotide polymorphisms to detect large genomic alterations in chromosomes of interest. Chromosomal imbalances and loss of heterozygosity (LOH) were estimated as described previously [3]. An overview of the targeted hotspots/whole genes and chromosomes is shown in Supplementary Table 1. Sequencing was performed with the Ion Torrent Personal Genome Machine or Ion S5 (Life Technologies). TERT promoter mutational status (C228T and C250T mutation) was assessed in a separate assay as described before (SNaPshot, Life Technologies) [3] .

\section{Survival}

All patients were followed until death or censored at date of last follow-up. Overall survival (OS) was measured from the date of diagnostic scan until date of death or censorship. Date of death was provided by patient records or the Municipal Personal Records Database. The database was developed and maintained at Erasmus MC, and locked on March 21st 2018.

\section{Statistical analysis}

All analyses were performed using R (3.3.2) and RStudio (1.0.44). Overall survival was measured as time between date of diagnostic scan and date of death or censorship. 
Overall survival is shown in Kaplan-Meier plots (ggplot2 package in R). Univariable analyses were performed using the Log-rank test and multivariable analyses with Cox proportional-hazards models. Categorical data were analyzed with Pearson's Chi square test or Fisher's exact test when assumptions of the Chi square test were violated (as indicated in the respective tables). Kruskal-Wallis test was used for continuous data. All calculations were twosided tests, with a $\mathrm{P}$ value $<0.05$ considered as statistically significant.

\section{Results}

We identified 246 patients with a pathologically confirmed grade II glioma with available FFPE material. Of these, 2 patients were excluded due to insufficient DNA yield and no remaining tissue for DNA isolation, and 14 were excluded from analysis due to sequencing failure (very low coverage and/or uniformity for most amplicons after two attempts). At the time of analysis, 53 patients were reported dead, 15 of the 95 IDH mutated 1p/19q-codeleted oligodendroglioma patients and 38 of the $112 \mathrm{IDH}$ mutated astrocytoma patients.

\section{Molecular classification}

As we were interested in additional markers for $I D H$ mutated grade II glioma, 23 patient samples that were classified as $I D H$ wildtype were excluded from further analyses. 207 patients were included in final analyses with a median follow-up of 6.9 years (range 0.4-21.7 years). Clinical characteristics are shown in Table 1. An oncoprint plot with all mutations and copy number alterations for the 207 patients is shown in Fig. 1. Mutation frequencies per molecular subgroup are shown in Table 2. Median overall survival per CNS WHO 2016 molecular subgroup was consistent with literature (Supplementary Fig. 1).

\section{IDH mutated astrocytoma}

107 of the $112 I D H$ mutated astrocytomas could be reliably evaluated for imbalance of chromosome 7: 13 samples showed imbalance compatible with trisomy of the entire chromosome 7. In univariable analysis trisomy of chromosome 7 was significantly associated with shorter overall survival ( $\log \operatorname{rank} P=0.044)$. However, this survival difference lost significance when correcting for age and KPS (HR 2.22; 95\% CI 0.95-5.20; $\mathrm{P}=0.066)$. Only two samples showed loss of entire chromosomal arm 10q, both with a relatively poor overall survival of less than 8 years (Fig. 2). Loss of $9 \mathrm{p} 21.3(\mathrm{n}=18)$ was not associated with outcome. Out of the 18 patients with loss of 9p21.3, 13 showed loss of the
Table 1 Patient characteristics

\begin{tabular}{|c|c|c|c|c|c|}
\hline \multirow[t]{2}{*}{ Characteristics } & \multicolumn{2}{|c|}{$\begin{array}{l}\text { Oligodendro- } \\
\text { glioma }\end{array}$} & \multicolumn{2}{|c|}{$\begin{array}{l}\text { Astrocytoma } \\
\text { IDHmt }\end{array}$} & \multirow[t]{2}{*}{$\mathrm{P}$} \\
\hline & $\mathrm{N}$ & $\%$ & $\mathrm{~N}$ & $\%$ & \\
\hline Patients (n) & 95 & & 112 & & \\
\hline Sex & & & & & 0.149 \\
\hline Male & 49 & 51.6 & 71 & 63.4 & \\
\hline Female & 46 & 48.4 & 41 & 36.6 & \\
\hline Age & & & & & $<0.0001$ \\
\hline Median (IQR) & 45 & $(37-52)$ & 37 & $(29-45)$ & \\
\hline Type of 1st surgery & & & & & $0.002^{\dagger}$ \\
\hline Awake craniotomy & 51 & 53.7 & 54 & 48.2 & \\
\hline Normal resection & 23 & 24.2 & 49 & 43.8 & \\
\hline Open biopsy & 7 & 7.4 & 2 & 1.8 & \\
\hline Stereotactic biopsy & 14 & 14.7 & 7 & 6.2 & \\
\hline Preoperative KPS & & & & & 0.064 \\
\hline Median (IQR) & 100 & $(100-100)$ & 100 & $(90-100)$ & \\
\hline \multicolumn{6}{|c|}{ Histopathological diagnosis } \\
\hline Grade II astrocytoma & 8 & 8.4 & 87 & 77.7 & \\
\hline $\begin{array}{l}\text { Grade II oligodendro- } \\
\text { glioma }\end{array}$ & 77 & 81.1 & 9 & 8.0 & \\
\hline $\begin{array}{l}\text { Grade II oligo-astro- } \\
\text { cytoma }\end{array}$ & 10 & 10.5 & 16 & 14.3 & \\
\hline $\begin{array}{l}\text { Treatment after 1st } \\
\text { surgery }\end{array}$ & & & & & $<0.0001$ \\
\hline Wait and scan & 52 & 54.7 & 52 & 46.4 & \\
\hline Chemotherapy & 24 & 25.3 & 5 & 4.5 & \\
\hline Radiotherapy & 16 & 16.8 & 42 & 37.5 & \\
\hline Chemoradiation & 3 & 3.2 & 13 & 11.6 & \\
\hline \multicolumn{6}{|l|}{ Follow-up (years) } \\
\hline Median (range) & 8.0 & $(0.9-21.7)$ & 6.1 & $(0.4-16.7)$ & \\
\hline
\end{tabular}

†Fisher's exact test

entire 9p chromosomal arm, which was also not associated with outcome. A PTEN mutation was detected in 3 patients (all three no loss of 10q) and did not show an impact on outcome (Fig. 2).

\section{IDH mutated 1p/19q-codeleted oligodendroglioma}

In $I D H$ mutated $1 \mathrm{p} / 19 \mathrm{q}$-codeleted oligodendroglioma, both $C I C$ and FUBPI mutations were frequent events, but neither was associated with prognosis (Fig. 3). In 27 out of the 77 patients that could be reliably evaluated for copy number changes on chromosome 9p, loss of 9p21.3 was found. Of these, 23 showed loss of entire chromosomal arm 9p. No homozygous deletions or mutations of $C D K N 2 A$ were detected. Loss of 9p21.3 did not have significant impact on overall survival ( $\log \operatorname{rank} \mathrm{P}=0.12)$ (Fig. 3). Additional analysis for impact of loss of entire $9 p$ did not show different results. Trisomy of chromosome 7 and loss of chromosomal arm 10q were present in a few samples, both without 


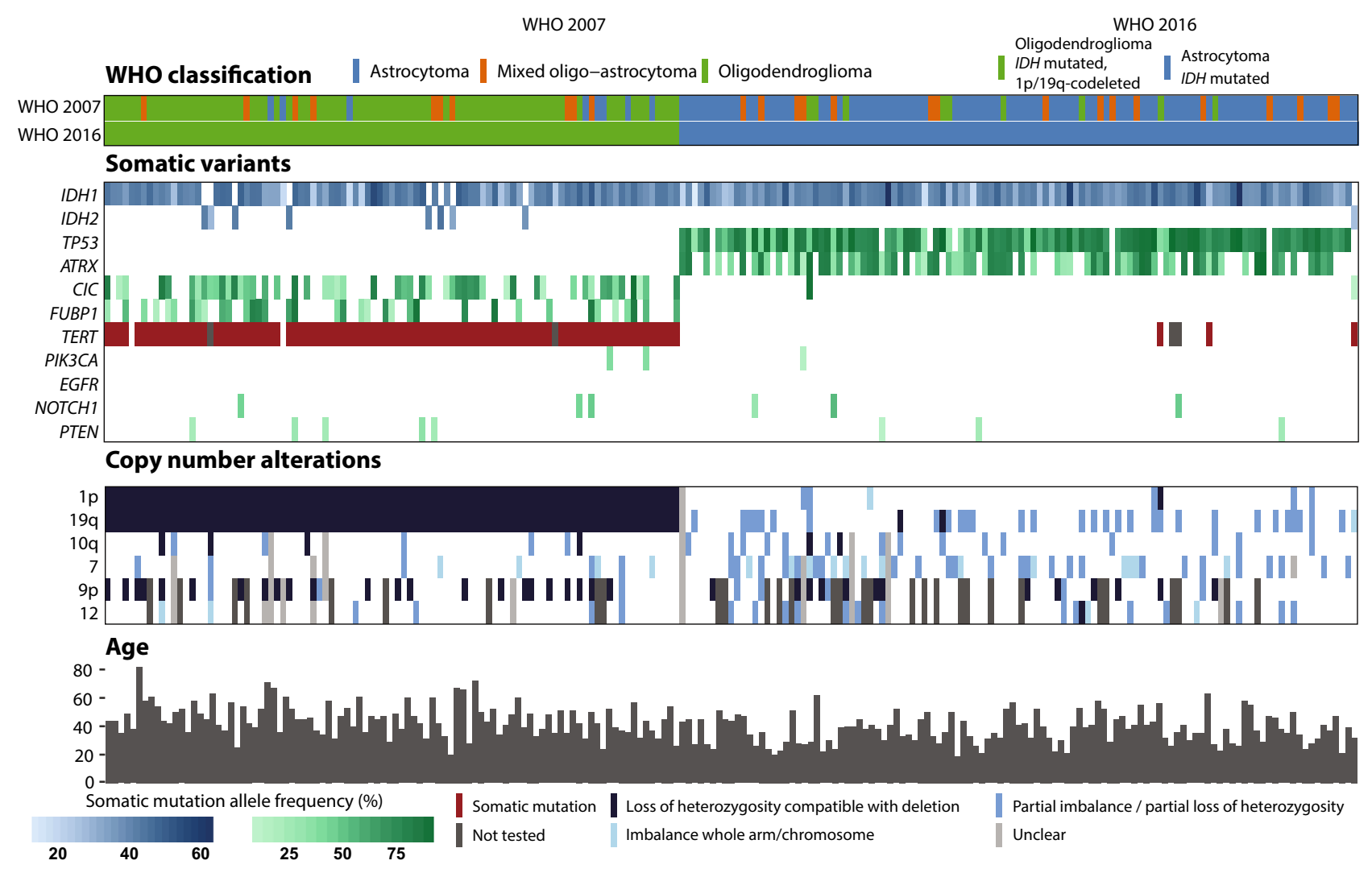

Fig. 1 Oncoprint plot with overview of somatic alterations per patient. At the top of the figure the WHO 2007 and WHO 2016 classification are shown. In the middle part all somatic variants and copy number alterations are shown. Patients are separated based on the

Table 2 Frequencies of gene mutations per WHO subgroup

\begin{tabular}{|c|c|c|c|c|}
\hline \multirow[t]{2}{*}{ Gene } & \multicolumn{2}{|c|}{ IDH mutated astrocytoma } & \multicolumn{2}{|c|}{$\begin{array}{l}\text { IDH mutated } \\
\text { 1p/19q-codeleted } \\
\text { oligodendro- } \\
\text { glioma }\end{array}$} \\
\hline & $\mathrm{N}$ & $\%$ & $\mathrm{~N}$ & $\%$ \\
\hline$I D H 1$ & 111 & 99.1 & 87 & 91.6 \\
\hline IDH2 & 1 & 0.9 & 8 & 8.4 \\
\hline TP53 & 105 & 93.8 & 0 & 0 \\
\hline ATRX & 75 & 67 & 0 & 0 \\
\hline CIC & 2 & 1.8 & 52 & 54.7 \\
\hline$F U B P 1$ & 0 & 0 & 36 & 37.9 \\
\hline TERT & 3 & 2.7 & 91 & 95.8 \\
\hline PIK $3 C A$ & 1 & 0.9 & 2 & 2.1 \\
\hline$E G F R$ & 0 & 0 & 0 & 0 \\
\hline NOTCH1 & 3 & 2.7 & 3 & 3.2 \\
\hline PTEN & 3 & 2.7 & 5 & 5.3 \\
\hline
\end{tabular}

impact on overall survival (Fig. 3). Five patients were PTEN mutated and showed a significantly shorter OS in univariable analysis ( $\log$ rank $\mathrm{P}=0.033)$. This survival difference was
WHO 2016 classification. IDH mutated 1p/19q-codeleted patients are depicted in the left part of the figure and $I D H$ mutated astrocytoma patients on the right part of the figure. The bottom part of the figure shows the clinical characteristic age per patient

not significant anymore when correcting for age and KPS (HR 3.73; 95\% CI 0.78-17.76; P=0.097).

\section{Exploratory analyses}

On further exploratory analyses, we found no other molecular markers that significantly impact on overall survival in molecularly defined LGG with the targeted sequencing panel we used.

\section{Validation of findings in the TCGA}

We aimed to validate our findings in the publically available dataset The Cancer Genome Atlas (TCGA). In the TCGA dataset, 9 out of 72 grade II IDH mutated astrocytoma showed trisomy of chromosome 7 , but this was not significantly associated with a difference in overall survival in univariate analysis $(\log \operatorname{rank} \mathrm{P}=0.3)$. We also analyzed the TCGA dataset for presence of loss of $10 \mathrm{q}$ in grade II $I D H$ mutated astrocytoma. Only one sample showed loss of 10q, with a poor survival (1.75 years). Among the 47 grade II IDH mutated 1p/19q-codeleted oligodendroglioma samples 

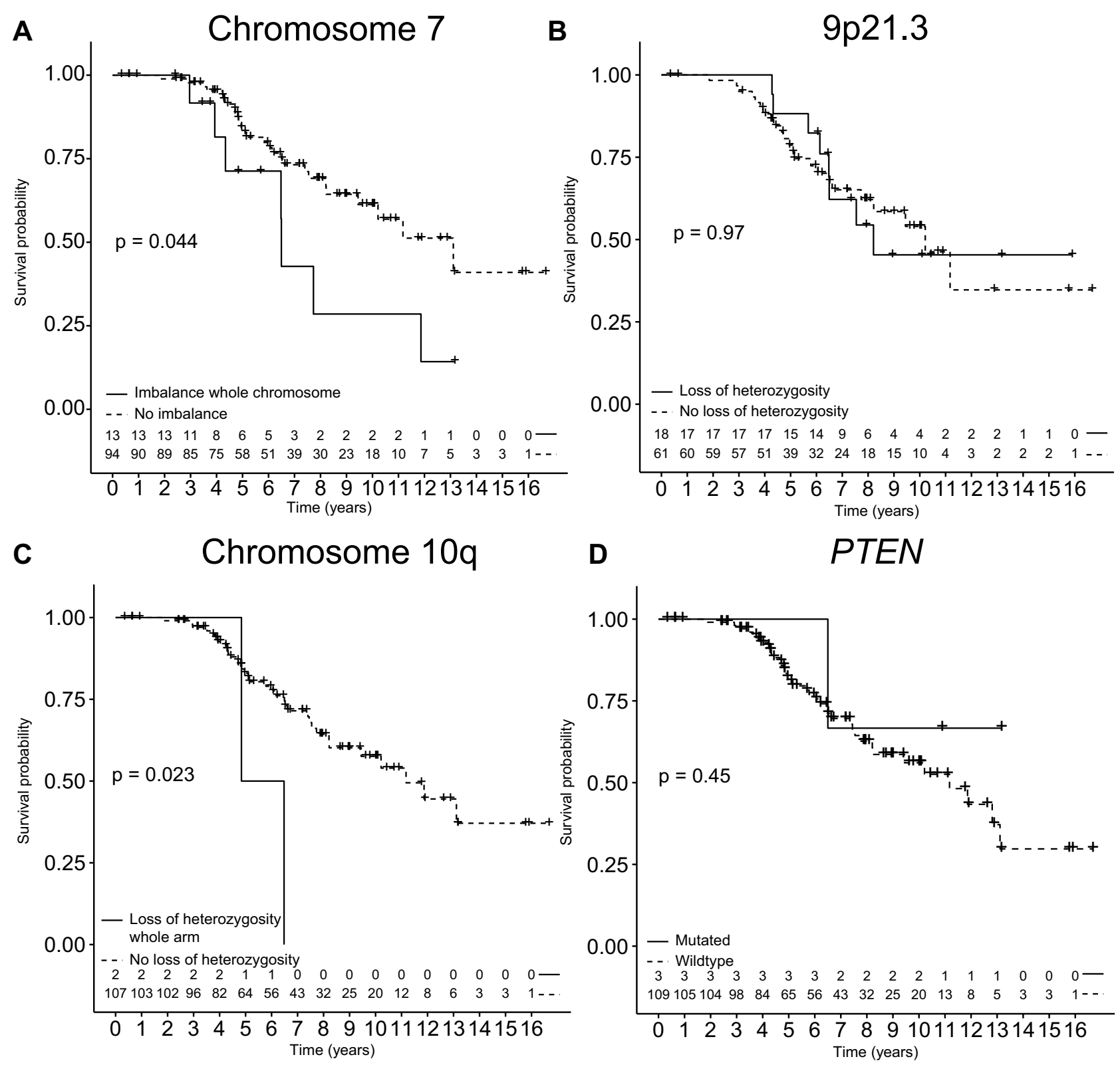

Fig. 2 Kaplan-Meier plots with overall survival of IDH mutated astrocytoma patients. Kaplan-Meier plots with overall survival of $I D H$ mutated astrocytoma patients stratified for presence of a imbal-

ance pattern consistent with trisomy of chromosome 7 , b loss of 9 p21.3 region, $\mathbf{c}$ loss of chromosomal arm 10q, $\mathbf{d}$ and presence of a PTEN mutation

in the TCGA dataset, there were no samples with a PTEN mutation, confirming the rarity of this event.

\section{Discussion}

In this study we aimed to investigate the prognostic impact of additional molecular markers in grade II $I D H$ mutated astrocytoma and grade II $I D H$ mutated $1 \mathrm{p} / 19 \mathrm{q}$-codeleted oligodendroglioma. We used a targeted NGS panel to investigate genes that are frequently mutated in glioma and to

investigate regions that are frequently reported to have copy number changes.

Loss of chromosome 9p or in particular the 9p21.3 region is a frequently reported copy number variation in all glioma subtypes [2, 9-11]. Several studies investigated the impact of loss of $9 \mathrm{p} / 9 \mathrm{p} 21.3$ on prognosis. A meta-analysis published in 2015 pooled the data of 13 different studies that were published between 2002 and 2013 [10]. Although most individual studies in this metaanalysis did not show a survival difference, the pooled data showed that loss of $9 p$ was significantly associated 
A

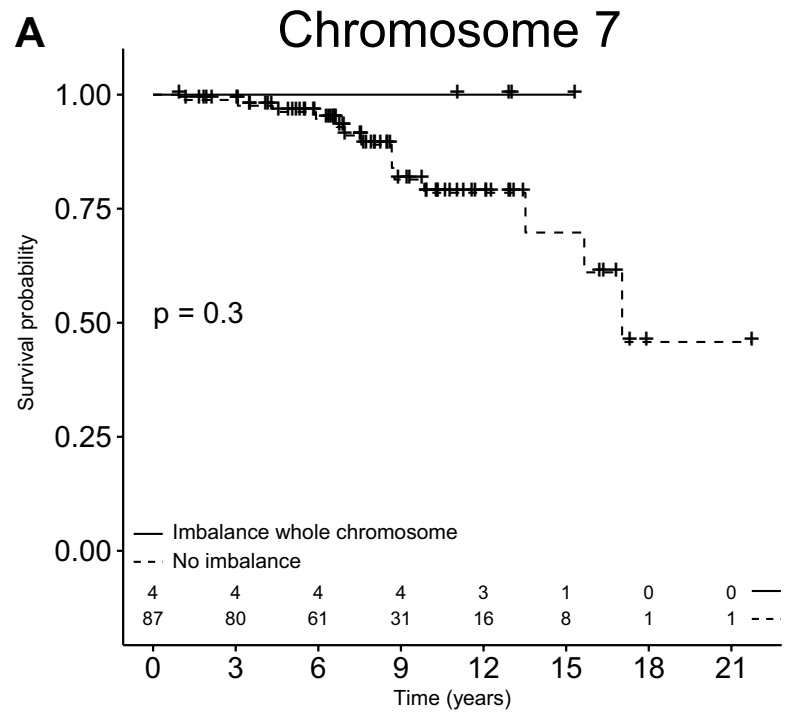

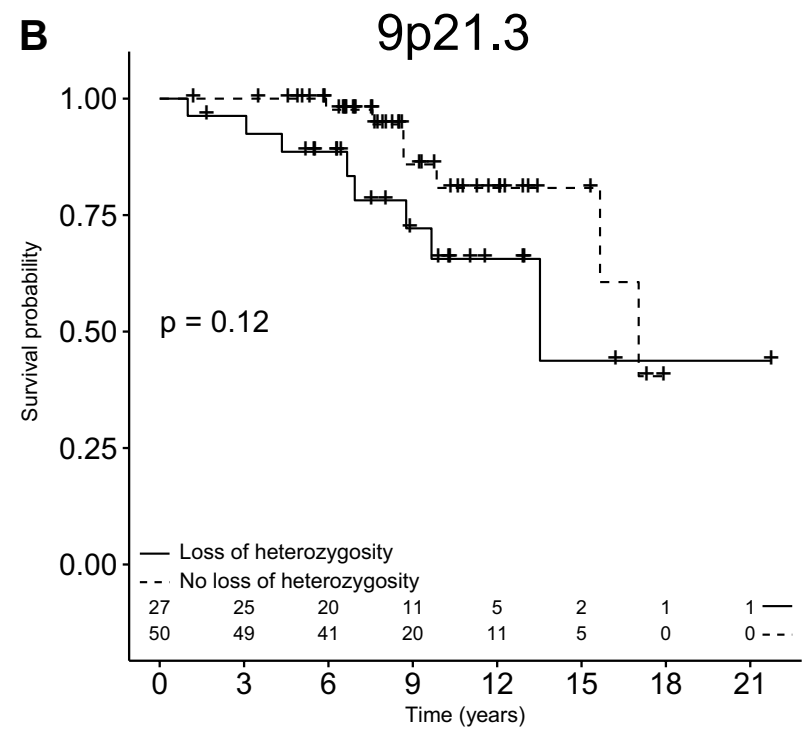

C

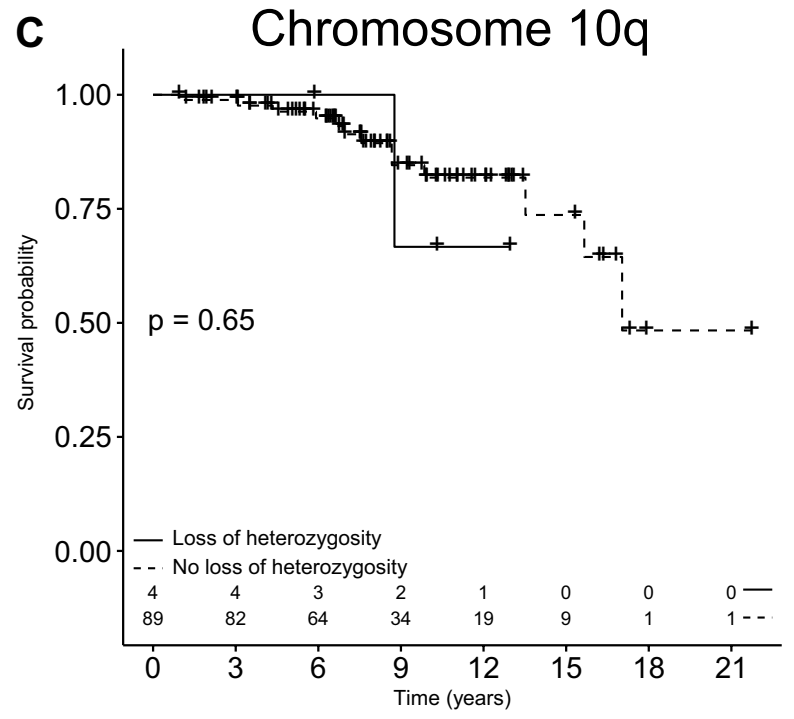

E

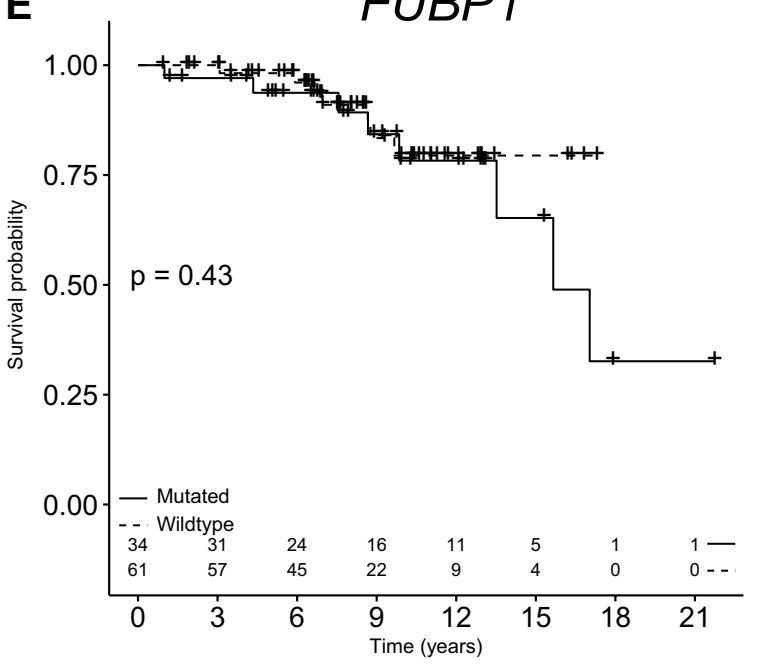

D
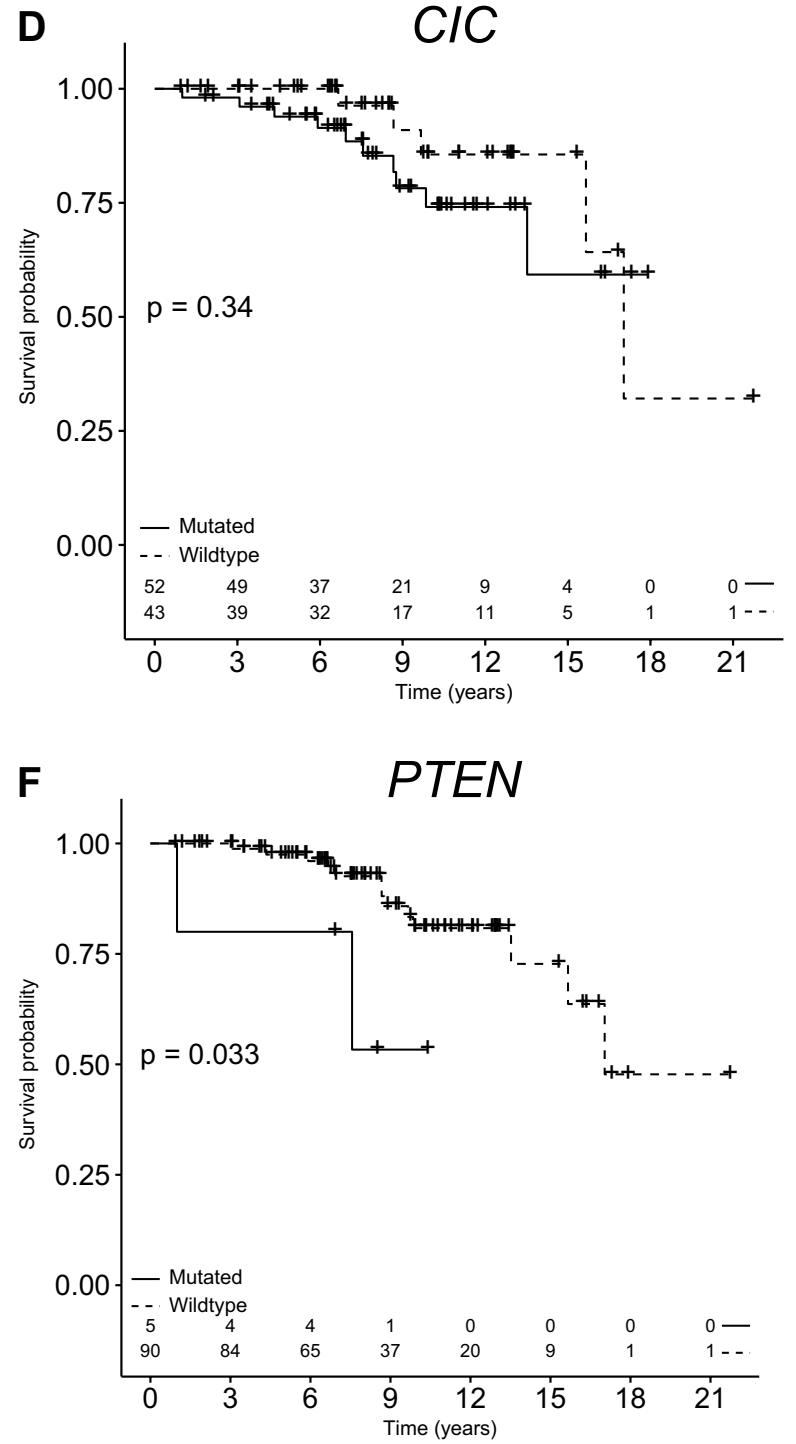
4Fig. 3 Kaplan-Meier plots with overall survival of IDH mutated 1p/19q-codeleted oligodendroglioma patients. Kaplan-Meier plots with overall survival of $I D H$ mutated $1 \mathrm{p} / 19 \mathrm{q}$-codeleted oligodendroglioma patients stratified for presence of a Imbalance pattern consistent with trisomy of chromosome 7 , b loss of 9p21.3 region, $\mathbf{c}$ loss of chromosomal arm 10q, $\mathbf{d}$ presence of $C I C$ mutation, e presence of FUBP1 mutation, $\mathbf{f}$ and presence of a PTEN mutation

with a poorer prognosis. However, most studies in this analysis did not take into account confounding factors such as $I D H 1 / 2$ mutational status, and a subgroup analysis of types of gliomas showed that impact of loss of $9 p$ on overall survival was particularly present in the glioblastoma subtype. A recent study specifically focused on the impact of $9 p$ loss in grade II and III glioma and found that loss of $9 p$ is an independent prognostic factor in IDH mutated glioma, however, the effect was most clear in $I D H$ mutated astrocytomas [11]. In opposite, Alentorn et al. found loss of $9 p$ to be a poor prognostic marker in anaplastic oligodendroglioma [9]. A later study by Aoki et al. did not confirm this finding however [12]. Our study is the first that specifically focusses on the impact of loss of $9 \mathrm{p} 21.3$ and entire $9 \mathrm{p}$ in histologically defined grade II glioma. We could not confirm impact of loss of 9 p21.3 region or entire 9p on prognosis in $I D H$ mutated astrocytoma nor in $I D H$ mutated 1p/19q-codeleted oligodendroglioma. However, a trend towards shorter overall survival in $I D H$ mutated $1 \mathrm{p} / 19 \mathrm{q}$-codeleted oligodendroglioma with loss of $9 \mathrm{p} 21.3$ is visible, and longer follow-up and larger sample size is necessary for final conclusions. Exact comparison of our data with previous literature is difficult, because of different selection criteria in the different cohorts. Therefore, it is yet unclear if in grade II $I D H$ mutated glioma loss of 9p21.3 region can be used as marker of anaplasia or to guide more aggressive treatment strategies.

Trisomy of chromosome 7 is also frequently reported in glioma [2, 14, 15]. In combination with loss of $10 \mathrm{q}$ it is considered an early event in glioblastoma $I D H$ wildtype and is correlated with dismal prognosis in grade II and III IDH wildtype glioma [2, 15-17]. Trisomy of chromosome 7 is also described in lower grade glioma, though less frequently. The impact of trisomy of 7 on overall survival in IDH mutated low grade glioma is not clear. To our knowledge no large series are published. Wessels et al. reported that polysomy of 7 was associated with a poorer prognosis in grade II astrocytoma, but this report antedates the discovery of the role IDH mutations in glioma [14]. In our cohort we found that trisomy of chromosome 7 might be a marker of poor prognosis in $I D H$ mutated astrocytoma. However, this could not be validated in multivariate analysis nor in the TCGA data, and this observation requires validation in a larger independent cohort to define the clinical value.

$C I C$ and $F U B P 1$ mutations are frequently mutated in IDH mutated 1p/19q-codeleted oligodendroglioma and the prognostic impact has been investigated in several series. One study by Gleize et al. reported that inactivating CIC mutations in $I D H$ mutated glioma correlate with poorer outcome. In other cohorts this effect was not observed [3, 18-20]. In our cohort we also did not find a correlation between $C I C$ nor FUBPI mutation and prognosis.

Our study has several limitations. The retrospective nature comes with the risk of a selection bias. We tried to avoid selection bias by analyzing a consecutive cohort of all grade II gliomas undergoing surgery within a specified period. Also due to the retrospective nature, treatment was heterogeneous. Furthermore, we may have missed smaller region copy number alterations and other mutations in regions not covered by our NGS panel. We used a diagnostically validated [21] and targeted NGS panel that consists of highly polymorphic SNPs that cover whole chromosomes of interest with roughly 1 SNP per $3 \mathrm{MB}$. Large scale copy number variations of whole chromosomes or large parts of chromosomes can therefore be reliably detected, but small region or subclonal copy number variations are potentially missed. However, the aim of this study was to validate the impact of large region copy number variations which were described before and that are considered to be early events, and these can be reliably detected with the panel used [21]. Also, it is known that lengthy follow-up in studies on low-grade glioma is necessary for definitive conclusions, so longer of follow up of this dataset is necessary.

In conclusion, in univariable analysis we found a significant shorter overall survival in $I D H$ mutated astrocytoma patients with trisomy of chromosome 7 , and in $I D H$ mutated 1p/19q-codeleted oligodendroglioma patients with a PTEN mutation. However, we could not confirm these findings in multivariate analysis or in the TCGA validation set and therefore these findings require validation in other larger series. We could not confirm the impact on OS of LOH of 9p21.3 (the CDKN2A region) which is frequently reported as a progression marker particularly in higher grade glioma. However, we need lengthy follow-up for definitive conclusions. Also, other strategies should be pursued to identify prognostic relevant molecular markers within these IDH mutant glioma subgroups, like methylation patterns and total number of chromosomal aberrations.

Author contributions MMJW, PJF, CMFD, AJPEV, and MJvdB contributed to the conception and design of the work. All authors contributed to the acquisition and interpretation of the data. MMJW, PJF, and MJVDB wrote the initial draft of the report. All authors critically reviewed each draft and provided feedback and intellectual content, and provided final approval to submit for publication. 


\section{Compliance with ethical standards}

Conflict of interest Martin J. van den Bent reports personal fees from Roche, Novartis, BMS, MSD, Actelion, Blue Earth Diagnostics, and personal fees and grants from Abbvie, all outside the submitted work. All other authors report no disclosures.

Ethical approval This article does not contain any studies with human participants or animals performed by any of the authors. This study was approved by the medical ethics committee of Erasmus MC.

Open Access This article is distributed under the terms of the Creative Commons Attribution 4.0 International License (http://creativeco mmons.org/licenses/by/4.0/), which permits unrestricted use, distribution, and reproduction in any medium, provided you give appropriate credit to the original author(s) and the source, provide a link to the Creative Commons license, and indicate if changes were made.

\section{References}

1. Louis DN, Perry A, Reifenberger G, von Deimling A, FigarellaBranger D, Cavenee WK, Ohgaki H, Wiestler OD, Kleihues P, Ellison DW (2016) The 2016 World Health Organization classification of tumors of the central nervous system: a summary. Acta Neuropathol 131:803-820. https://doi.org/10.1007/s0040 1-016-1545-1

2. Cancer Genome Atlas Research N, Brat DJ, Verhaak RG, Aldape KD, Yung WK, Salama SR, Cooper LA, Rheinbay E, Miller CR, Vitucci M, Morozova O, Robertson AG, Noushmehr H, Laird PW, Cherniack AD, Akbani R, Huse JT, Ciriello G, Poisson LM, Barnholtz-Sloan JS, Berger MS, Brennan C, Colen RR, Colman H, Flanders AE, Giannini C, Grifford M, Iavarone A, Jain R, Joseph I, Kim J, Kasaian K, Mikkelsen T, Murray BA, O'Neill BP, Pachter L, Parsons DW, Sougnez C, Sulman EP, Vandenberg SR, Van Meir EG, von Deimling A, Zhang H, Crain D, Lau K, Mallery D, Morris S, Paulauskis J, Penny R, Shelton T, Sherman M, Yena P, Black A, Bowen J, Dicostanzo K, Gastier-Foster J, Leraas KM, Lichtenberg TM, Pierson CR, Ramirez NC, Taylor C, Weaver S, Wise L, Zmuda E, Davidsen T, Demchok JA, Eley G, Ferguson ML, Hutter CM, Mills Shaw KR, Ozenberger BA, Sheth M, Sofia HJ, Tarnuzzer R, Wang Z, Yang L, Zenklusen JC, Ayala B, Baboud J, Chudamani S, Jensen MA, Liu J, Pihl T, Raman R, Wan Y, Wu Y, Ally A, Auman JT, Balasundaram M, Balu S, Baylin SB, Beroukhim R, Bootwalla MS, Bowlby R, Bristow CA, Brooks D, Butterfield Y, Carlsen R, Carter S, Chin L, Chu A, Chuah E, Cibulskis K, Clarke A, Coetzee SG, Dhalla N, Fennell T, Fisher S, Gabriel S, Getz G, Gibbs R, Guin R, Hadjipanayis A, Hayes DN, Hinoue T, Hoadley K, Holt RA, Hoyle AP, Jefferys SR, Jones S, Jones CD, Kucherlapati R, Lai PH, Lander E, Lee S, Lichtenstein L, Ma Y, Maglinte DT, Mahadeshwar HS, Marra MA, Mayo M, Meng S, Meyerson ML, Mieczkowski PA, Moore RA, Mose LE, Mungall AJ, Pantazi A, Parfenov M, Park PJ, Parker JS, Perou CM, Protopopov A, Ren X, Roach J, Sabedot TS, Schein J, Schumacher SE, Seidman JG, Seth S, Shen H, Simons JV, Sipahimalani P, Soloway MG, Song X, Sun H, Tabak B, Tam A, Tan D, Tang J, Thiessen N, Triche T Jr, Van Den Berg DJ, Veluvolu U, Waring $\mathrm{S}$, Weisenberger DJ, Wilkerson MD, Wong T, Wu J, Xi L, Xu AW, Yang L, Zack TI, Zhang J, Aksoy BA, Arachchi H, Benz C, Bernard B, Carlin D, Cho J, DiCara D, Frazer S, Fuller GN, Gao J, Gehlenborg N, Haussler D, Heiman DI, Iype L, Jacobsen A, Ju Z, Katzman S, Kim H, Knijnenburg T, Kreisberg RB,
Lawrence MS, Lee W, Leinonen K, Lin P, Ling S, Liu W, Liu Y, Liu Y, Lu Y, Mills G, Ng S, Noble MS, Paull E, Rao A, Reynolds S, Saksena G, Sanborn Z, Sander C, Schultz N, Senbabaoglu Y, Shen R, Shmulevich I, Sinha R, Stuart J, Sumer SO, Sun Y, Tasman N, Taylor BS, Voet D, Weinhold N, Weinstein JN, Yang D, Yoshihara K, Zheng S, Zhang W, Zou L, Abel T, Sadeghi S, Cohen ML, Eschbacher J, Hattab EM, Raghunathan A, Schniederjan MJ, Aziz D, Barnett G, Barrett W, Bigner DD, Boice L, Brewer C, Calatozzolo C, Campos B, Carlotti CG Jr, Chan TA, Cuppini L, Curley E, Cuzzubbo S, Devine K, DiMeco F, Duell R, Elder JB, Fehrenbach A, Finocchiaro G, Friedman W, Fulop J, Gardner J, Hermes B, Herold-Mende C, Jungk C, Kendler A, Lehman NL, Lipp E, Liu O, Mandt R, McGraw M, McLendon R, McPherson C, Neder L, Nguyen P, Noss A, Nunziata R, Ostrom QT, Palmer C, Perin A, Pollo B, Potapov A, Potapova O, Rathmell WK, Rotin D, Scarpace L, Schilero C, Senecal K, Shimmel K, Shurkhay V, Sifri S, Singh R, Sloan AE, Smolenski K, Staugaitis SM, Steele R, Thorne L, Tirapelli DP, Unterberg A, Vallurupalli M, Wang Y, Warnick R, Williams F, Wolinsky Y, Bell S, Rosenberg M, Stewart C, Huang F, Grimsby JL, Radenbaugh AJ, Zhang J (2015) Comprehensive, integrative genomic analysis of diffuse lower-grade gliomas. N Engl J Med 372:2481-2498. https://doi.org/10.1056/NEJMoa1402121

3. Dubbink HJ, Atmodimedjo PN, Kros JM, French PJ, Sanson M, Idbaih A, Wesseling P, Enting R, Spliet W, Tijssen C, Dinjens WN, Gorlia T, van den Bent MJ (2016) Molecular classification of anaplastic oligodendroglioma using Next-Generation Sequencing: a report of the prospective randomized EORTC Brain Tumor Group 26951 phase III trial. Neuro Oncol 18:388-400. https://doi. org/10.1093/neuonc/nov182

4. Weller M, Weber RG, Willscher E, Riehmer V, Hentschel B, Kreuz M, Felsberg J, Beyer U, Loffler-Wirth H, Kaulich K, Steinbach JP, Hartmann C, Gramatzki D, Schramm J, Westphal M, Schackert G, Simon M, Martens T, Bostrom J, Hagel C, Sabel M, Krex D, Tonn JC, Wick W, Noell S, Schlegel U, Radlwimmer B, Pietsch T, Loeffler M, von Deimling A, Binder H, Reifenberger G (2015) Molecular classification of diffuse cerebral WHO grade II/III gliomas using genome- and transcriptome-wide profiling improves stratification of prognostically distinct patient groups. Acta Neuropathol 129:679-693. https://doi.org/10.1007/s0040 1-015-1409-0

5. Eckel-Passow JE, Lachance DH, Molinaro AM, Walsh KM, Decker PA, Sicotte H, Pekmezci M, Rice T, Kosel ML, Smirnov IV, Sarkar G, Caron AA, Kollmeyer TM, Praska CE, Chada AR, Halder C, Hansen HM, McCoy LS, Bracci PM, Marshall R, Zheng S, Reis GF, Pico AR, O'Neill BP, Buckner JC, Giannini C, Huse JT, Perry A, Tihan T, Berger MS, Chang SM, Prados MD, Wiemels J, Wiencke JK, Wrensch MR, Jenkins RB (2015) Glioma groups based on $1 \mathrm{p} / 19 \mathrm{q}$, IDH, and TERT promoter mutations in tumors. N Engl J Med 372:2499-2508. https://doi.org/10.1056/ NEJMoa1407279

6. Ryken TC, Parney I, Buatti J, Kalkanis SN, Olson JJ (2015) The role of radiotherapy in the management of patients with diffuse low grade glioma: a systematic review and evidence-based clinical practice guideline. J Neurooncol 125:551-583. https://doi. org/10.1007/s11060-015-1948-1

7. Soffietti R, Baumert BG, Bello L, von Deimling A, Duffau H, Frenay M, Grisold W, Grant R, Graus F, Hoang-Xuan K, Klein M, Melin B, Rees J, Siegal T, Smits A, Stupp R, Wick W, European Federation of Neurological S (2010) Guidelines on management of low-grade gliomas: report of an EFNS-EANO Task Force. Eur J Neurol 17:1124-1133. https://doi.org/10.111 1/j.1468-1331.2010.03151.x

8. Schiff D (2017) Low-grade gliomas. Continuum 23:1564-1579. https://doi.org/10.1212/CON.0000000000000537 
9. Alentorn A, Dehais C, Ducray F, Carpentier C, Mokhtari K, Figarella-Branger D, Chinot O, Cohen-Moyal E, Ramirez C, Loiseau $\mathrm{H}$, Elouahdani-Hamdi S, Beauchesne P, Langlois O, Desenclos C, Guillamo JS, Dam-Hieu P, Ghiringhelli F, Colin P, Godard J, Parker F, Dhermain F, Carpentier AF, Frenel JS, Menei P, Bauchet L, Faillot T, Fesneau M, Fontaine D, Motuo-Fotso MJ, Vauleon E, Gaultier C, Le Guerinel C, Gueye EM, Noel G, Desse N, Durando X, Barrascout E, Wager M, Ricard D, Carpiuc I, Delattre JY, Idbaih A, Network P (2015) Allelic loss of 9p21.3 is a prognostic factor in $1 \mathrm{p} / 19 \mathrm{q}$ codeleted anaplastic gliomas. Neurology 85:1325-1331. https://doi.org/10.1212/WNL.0000000000002014

10. Huang T, Li S, Yang Z, Liu J, Han Y (2016) Loss of heterozygosity of $9 p$ Is associated with poorer survival in patients with gliomas. Mol Neurobiol 53:6407-6412. https://doi.org/10.1007/ s12035-015-9523-5

11. Roy DM, Walsh LA, Desrichard A, Huse JT, Wu W, Gao J, Bose P, Lee W, Chan TA (2016) Integrated genomics for pinpointing survival loci within arm-level somatic copy number alterations. Cancer Cell 29:737-750. https://doi.org/10.1016/j.ccell .2016 .03 .025

12. Aoki K, Nakamura H, Suzuki H, Matsuo K, Kataoka K, Shimamura T, Motomura K, Ohka F, Shiina S, Yamamoto T, Nagata Y, Yoshizato T, Mizoguchi M, Abe T, Momii Y, Muragaki Y, Watanabe R, Ito I, Sanada M, Yajima H, Morita N, Takeuchi I, Miyano S, Wakabayashi T, Ogawa S, Natsume A (2017) Prognostic relevance of genetic alterations in diffuse lower-grade gliomas. Neuro Oncol. https://doi.org/10.1093/neuonc/nox132

13. Wijnenga MMJ, French PJ, Dubbink HD, Dinjens WNM, Atmodimedjo PN, Kros JM, Smits M, Gahrmann R, Rutten GJ, Verheul JB, Fleischeuer R, Dirven CMF, Vincent AJPE, van den Bent MJ (2017) The impact of surgery in molecularly defined lowgrade glioma: an integrated clinical, radiological and molecular analysis. Neuro Oncol. https://doi.org/10.1093/neuonc/nox176

14. Wessels PH, Twijnstra A, Kessels AG, Krijne-Kubat B, Theunissen PH, Ummelen MI, Ramaekers FC, Hopman AH (2002) Gain of chromosome 7, as detected by in situ hybridization, strongly correlates with shorter survival in astrocytoma grade 2 . Genes Chromosomes Cancer 33:279-284. https://doi.org/10.1002/ gcc. 10029
15. van den Bent MJ, Weller M, Wen PY, Kros JM, Aldape K, Chang S (2017) A clinical perspective on the 2016 WHO brain tumor classification and routine molecular diagnostics. Neuro Oncol 19:614-624. https://doi.org/10.1093/neuonc/now277

16. Aibaidula A, Chan AK, Shi Z, Li Y, Zhang R, Yang R, Li KK, Chung NY, Yao Y, Zhou L, Wu J, Chen H, Ng HK (2017) Adult IDH wild-type lower-grade gliomas should be further stratified. Neuro Oncol 19:1327-1337. https://doi.org/10.1093/neuonc/ nox078

17. Wijnenga MMJ, Dubbink HJ, French PJ, Synhaeve NE, Dinjens WNM, Atmodimedjo PN, Kros JM, Dirven CMF, Vincent A, van den Bent MJ (2017) Molecular and clinical heterogeneity of adult diffuse low-grade IDH wild-type gliomas: assessment of TERT promoter mutation and chromosome 7 and 10 copy number status allows superior prognostic stratification. Acta Neuropathol 134:957-959. https://doi.org/10.1007/s00401-017-1781-z

18. Wesseling P, van den Bent M, Perry A (2015) Oligodendroglioma: pathology, molecular mechanisms and markers. Acta Neuropathol 129:809-827. https://doi.org/10.1007/s00401-015-1424-1

19. Chan AK, Pang JC, Chung NY, Li KK, Poon WS, Chan DT, Shi Z, Chen L, Zhou L, Ng HK (2014) Loss of CIC and FUBP1 expressions are potential markers of shorter time to recurrence in oligodendroglial tumors. Mod Pathol 27:332-342. https://doi. org/10.1038/modpathol.2013.165

20. Jiao Y, Killela PJ, Reitman ZJ, Rasheed AB, Heaphy CM, de Wilde RF, Rodriguez FJ, Rosemberg S, Oba-Shinjo SM, Nagahashi Marie SK, Bettegowda C, Agrawal N, Lipp E, Pirozzi C, Lopez G, He Y, Friedman H, Friedman AH, Riggins GJ, Holdhoff M, Burger P, McLendon R, Bigner DD, Vogelstein B, Meeker AK, Kinzler KW, Papadopoulos N, Diaz LA, Yan H (2012) Frequent ATRX, CIC, FUBP1 and IDH1 mutations refine the classification of malignant gliomas. Oncotarget 3:709-722. https://doi. org/10.18632/oncotarget.588

21. Dubbink HJ, Atmodimedjo PN, van Marion R, Krol NM, Riegman PH, Kros JM, van den Bent MJ, Dinjens WN (2016) Diagnostic detection of allelic losses and imbalances by Next-Generation Sequencing: $1 \mathrm{p} / 19 \mathrm{q}$ co-deletion analysis of gliomas. J Mol Diagn 18:775-786. https://doi.org/10.1016/j.jmoldx.2016.06.002 